\title{
Perceived barriers to weight maintenance among university students in Kuwait: the role of gender and obesity
}

\author{
Abdulrahman O. Musaiger · Fawzia I. Al-Kandari • \\ Mariam Al-Mannai - Alaa M. Al-Faraj - Fajer A. Bouriki • \\ Fatima S. Shehab - Lulwa A. Al-Dabous - Wassin B. Al-Qalaf
}

Received: 20 September 2013/ Accepted: 25 December 2013/Published online: 9 January 2014

(C) The Japanese Society for Hygiene 2014

\begin{abstract}
Objective To investigate the barriers to weight maintenance among university students in Kuwait by gender and obesity.

Methods A sample of 530 students was selected at convenience from four universities in Kuwait (2 public and 2 private). The age of students ranged from 19 to 26 years. A self-reported pretested questionnaire was used to obtain the barriers, which were divided into barriers to healthy eating and barriers to physical activity. Weight and height were based on self-reporting, and the students were grouped into non-obese and obese according to the WHO classification. The response options to barriers were: very important, somewhat important and not important.

Results The main barriers to healthy eating for both genders were: "Do not have skills to plan, shop for, prepare or cook healthy foods" and "Not having time to prepare or eat healthy food". In general, there were no significant differences between men and women in barriers to healthy eating. There were highly significant differences between men and women regarding barriers to physical activity ( $P$ values ranged from $<0.001$ to $<0.016$ ). "Not having time to be physically active" and "The climate is not
\end{abstract}

A. O. Musaiger $(\square)$

Arab Centre for Nutrition, P.O. Box 26923, Manama,

Kingdom of Bahrain

e-mail: amusaiger@gmail.com

F. I. Al-Kandari · A. M. Al-Faraj · F. A. Bouriki ·

F. S. Shehab - L. A. Al-Dabous · W. B. Al-Qalaf

College of Medicine and Medical Sciences Arabian Gulf

University, Manama, Kingdom of Bahrain

M. Al-Mannai

Department of Mathematics, College of Science, University

of Bahrain, Manama, Kingdom of Bahrain suitable for practising exercise" were the main barriers reported. Obese men were more likely to face barriers to healthy eating than non-obese men. There were no significant differences between obese and non-obese women regarding barriers to healthy eating and physical activity. Conclusion The findings of this study can be utilized in intervention activities to promote a healthy lifestyle and to combat obesity in Kuwait, and maybe in other Arab countries.

Keywords Barriers to weight maintenance - Healthy eating $\cdot$ Physical activity $\cdot$ Obesity $\cdot$ Kuwait

\section{Introduction}

Obesity has received a great deal of attention worldwide as one of the main risk factors for non-communicable diseases [1]. The prevalence of obesity in Kuwait, both in children and adults, is considered one of the highest in the world, as data have shown that 78 and $82 \%$ of men and women in Kuwait are overweight and obese, respectively [2]. Obesity is associated with several social, psychological and environmental factors that may interfere with healthy eating and physical activity [3]. Such factors differ across communities, and therefore each community needs to investigate the particular components that may be an obstacle to eating a healthy diet and to practising physical activity.

Studies in Kuwait have focused on factors associated with obesity among children [4, 5] and adults [6, 7]; however, none of these studies have investigated the barriers to weight maintenance. Barriers to healthy eating and physical activity may contribute to obesity. Prior studies in Western countries have reported several social and environmental barriers to weight maintenance $[8,9]$. However, 
our knowledge of the possible barriers that contribute to obesity among Arab communities has been impeded by the limited information on barriers to controlling diet and practising a healthy lifestyle.

Young adults (aged 19-30 years) are rarely investigated in the Arab world, as the focus is mainly on children ( $<19$ years) or adults ( $>30$ years). In Kuwait, Al-Isa [10] found that $34.4 \%$ of university women were overweight or obese; the prevalence among university men was $49.6 \%$ [11]. The prevalence reached an alarming level in 2009 as El-Ghazali et al. [12] found that about $93 \%$ of both male and female university students were overweight or obese, and that their dietary habits were characterized by the high consumption of fast foods and sweets. Among these students, $10.8 \%$ of males and $13.4 \%$ of females were physically active.

The high rate of obesity and the low prevalence of physical activity among university students in Kuwait have created the need to establish a programme to promote a healthy lifestyle for this section of the population. Such a programme would not be effective if it did not include activities to overcome barriers to weight maintenance. To our knowledge, no studies have focused on barriers to weight maintenance among university students in Arab countries in general and in Kuwait in particular. Therefore, the current study aimed to investigate the perceived personal, social and environmental barriers to healthy eating and physical activity among university students in Kuwait, as well as the association of gender and weight status with these barriers.

\section{Methods}

\section{Participants}

The target group was university students at public and private universities. The total sample comprised 530 students (203 males and 327 females); of these 333 were selected from two government universities and 197 students from two private universities in Kuwait. The ages of students ranged from 19 to 26 years. The students were selected at convenience and interviewed during their break times and lunch break by Kuwaiti medical students. One to two medical students were visited at the colleges and the data collected, either in the cafeteria where the participants gathered for snacking or lunch break or in the main hall of the colleges. The medical students explained the purpose of the study to the participants and gave them the choice to accept to participate in the study or deny. Then the questionnaire was distributed to those who agreed to participate and they were asked to fill it on the spot in the presence of the medical students. The study was ethically approved by the Family and Community Medicine Department at the
College of Medicine and Medical Sciences at the Arabian Gulf University, Bahrain. Data were collected during July and August 2010.

\section{Questionnaire}

The questionnaire was based on statements related to barriers to healthy eating and physical activity that had been previously published and used a validated self-reported questionnaire on young women [13]. Some statements were modified to adjust them to the Arab culture as the base study was carried out in Australia. The Arabic version of the questionnaire consisted of 10 statements related to barriers to healthy eating and 14 statements related to barriers to physical activity. The barriers were divided into personal, social and environmental. Response options to the statements about the barriers were: not important, somewhat important and very important.

The Arabic version of the questionnaire had been previously tested on 628 Kuwaiti secondary students, and Cronbach's alpha coefficient reliability test was applied. The values of Cronbach's alpha coefficient for the statements related to healthy eating were between 0.652 and 0.686 , while the values for those related to physical activity ranged from 0.711 to 0.762 ; this indicated moderate internal reliability, which was very close to the original English version [13]. Detailed information on the validation and reliability of the questionnaire has been described elsewhere [14]. The reproducibility of the Arabic version of the questionnaire used in Musaiger et al. study [14] was measured using Cronbach's alpha coefficient. It was found that the value of Cronbach's alpha coefficient for the current questionnaire was 0.877 , suggesting a very good reliability to reproduce this questionnaire.

\section{Obesity measurement}

Weight and height of the students were provided by selfreporting, and students who did not know their weight and/ or height were not included in the study. Obesity was calculated using the body mass index (BMI) according to the recommendations of the World Health Organization [1] as follows: "normal (BMI; 18.5 to $<25 \mathrm{~kg} / \mathrm{m}^{2}$ ), overweight (BMI; 25 to $<30 \mathrm{~kg} / \mathrm{m}^{2}$ ) and obese (BMI $\left.>30 \mathrm{~kg} / \mathrm{m}^{2}\right)$ ". For the purpose of analysis the students were divided into two categories: non-obese $(\mathrm{BMI}<24.9)$ and obese $(\mathrm{BMI}>24.9)$.

Data analysis

The data were analysed using SPSS statistical package, version 17. The Chi-square test was used to measure the association between gender and obesity and the barriers. 


\section{Results}

Mean values for age and anthropometric characteristics of university students are shown in Table 1 . The mean age for men was 21.5 year compared to 20.6 year for women. The difference was statistically significant $(P<0.001)$. However, there were no significant differences between genders and age, when grouping the age to less than 21 and over 21 years. There were significant differences between men and women in relation to mean weight, height and BMI $(P<0.001)$.

The percentages of university students in Kuwait reporting of perceived barriers to healthy eating by gender are presented in Table 2. In general, men were more likely to report that these barriers were very important than women. "Do not have skills to plan, shop for, prepare or cook healthy foods" and "Not having time to prepare or eat healthy foods because of university commitment" were the main barriers to healthy eating perceived by the students. For the combined response categories of very important

Table 1 Mean values for age and anthropometric characteristics of university students

\begin{tabular}{lrrrrrrr}
\hline Characteristics & \multicolumn{2}{l}{ Mean } & & \multicolumn{2}{c}{ Standard deviation } & $P$ value \\
\cline { 2 - 3 } & Men & Women & & Men & Women & \\
\hline Age (Years) & 21.5 & 20.6 & & 3.5 & 2.6 & $<0.001$ \\
Weight $(\mathrm{kg})$ & 79.4 & 59.2 & & 14.4 & 11.6 & $<0.001$ \\
Height $(\mathrm{cm})$ & 174.3 & 161.0 & & 10.5 & 7.1 & $<0.001$ \\
BMI & 26.5 & 22.9 & & 7.5 & 4.9 & $<0.001$ \\
\hline
\end{tabular}

and somewhat important, $69 \%$ of men and $70 \%$ of women reported the first barrier; whereas the proportions reporting the second barrier were 66.5 and $76.8 \%$ for men and women, respectively. There were no significant differences between men and women in perceiving these barriers, except for the barriers related to lack of time to prepare or eat healthy foods because of university commitment $(P<0.012)$.

The proportions of university students in Kuwait reporting each of perceived barriers to physical activity by gender are given in Table 3. Except for three barriers, there were highly significant differences between men and women regarding barriers to physical activity ( $P$ values ranged from $<0.001$ to $<0.016$ ). Men were more likely than women to report most of the barriers to physical activity as not important. The main barriers to physical activity for both males and females were: "Not having time to be physically active" and "The climate is not suitable for practising exercise". Approximately 38 and $35 \%$ of men reported the former as very important and somewhat important, respectively, compared to 55 and $31 \%$ of women, respectively. The corresponding proportions for the second of these barriers were 35.5 and $42.9 \%$ among men and 58.7 and $30.9 \%$ among women.

The association between obesity among university students in Kuwait with perceived barriers to healthy eating by gender is shown in Table 4. Obese men had a greater tendency to report most of barriers to healthy eating as very important or somewhat important than non-obese men. This phenomenon was not clearly observed among women. There was a significant differences $(P<0.001)$ between

Table 2 Perceived barriers to healthy eating among university students in Kuwait by gender

\begin{tabular}{|c|c|c|c|c|c|c|c|}
\hline \multirow[t]{2}{*}{ Barriers } & \multicolumn{3}{|c|}{$\operatorname{Men}(N=203)$} & \multicolumn{3}{|c|}{ Women $(N=327)$} & \multirow[t]{2}{*}{$P$ value } \\
\hline & $\begin{array}{l}\text { Very imp } \\
(\%)\end{array}$ & $\begin{array}{l}\text { S. imp } \\
(\%)\end{array}$ & $\begin{array}{l}\text { Not imp } \\
(\%)\end{array}$ & $\begin{array}{l}\text { Very imp } \\
(\%)\end{array}$ & $\begin{array}{l}\text { S. imp } \\
(\%)\end{array}$ & $\begin{array}{l}\text { Not imp } \\
(\%)\end{array}$ & \\
\hline \multicolumn{8}{|l|}{ Personal and environmental barriers to healthy eating } \\
\hline 1. Do not have enough information about a healthy diet & 20.2 & 37.9 & 41.9 & 15.3 & 41.0 & 43.7 & 0.341 \\
\hline 2. Do not have motivation to eat healthy diet & 18.2 & 40.40 & 41.4 & 16.8 & 40.4 & 42.8 & 0.903 \\
\hline 3. Do not enjoy eating healthy foods & 24.6 & 41.4 & 34.0 & 16.8 & 42.5 & 40.7 & 0.068 \\
\hline $\begin{array}{l}\text { 4. Do not have skills to plan, shop for, prepare or cook healthy } \\
\text { foods }\end{array}$ & 24.6 & 44.3 & 31.0 & 24.2 & 45.9 & 29.9 & 0.940 \\
\hline 5. Do not have access to healthy foods & 24.1 & 34.0 & 41.9 & 19.6 & 37.9 & 42.5 & 0.413 \\
\hline 6. Not able to buy healthy foods that are inexpensive & 11.8 & 24.6 & 63.6 & 7.6 & 19.3 & 73.1 & 0.058 \\
\hline \multicolumn{8}{|l|}{ Social barriers to healthy eating } \\
\hline 1. No parent's support to eat healthy diet & 13.8 & 23.2 & 63.0 & 11.9 & 19.9 & 68.2 & 0.477 \\
\hline 2. No friend's support to eat healthy diet & 20.2 & 33.0 & 46.8 & 18.3 & 31.8 & 49.9 & 0.771 \\
\hline 3. No teacher's support to eat healthy diet & 25.6 & 26.6 & 47.8 & 19.6 & 29.1 & 51.3 & 0.261 \\
\hline $\begin{array}{l}\text { 4. Not having time to prepare or eat healthy foods because of } \\
\text { university commitment }\end{array}$ & 31.5 & 35.0 & 33.5 & 42.5 & 34.3 & 23.2 & 0.012 \\
\hline
\end{tabular}

Very imp very important barrier, S. imp somewhat important barrier, Not imp not important barrier 
Table 3 Perceived barriers to physical activity among university students in Kuwait by gender

\begin{tabular}{|c|c|c|c|c|c|c|c|}
\hline \multirow[t]{2}{*}{ Barriers } & \multicolumn{3}{|c|}{$\operatorname{Men}(N=203)$} & \multicolumn{3}{|c|}{ Women $(N=327)$} & \multirow[t]{2}{*}{$P$ value } \\
\hline & $\begin{array}{l}\text { Very imp } \\
(\%)\end{array}$ & $\begin{array}{l}\text { S. imp } \\
(\%)\end{array}$ & $\begin{array}{l}\text { Not imp } \\
(\%)\end{array}$ & $\begin{array}{l}\text { Very imp } \\
(\%)\end{array}$ & $\begin{array}{l}\text { S. imp } \\
(\%)\end{array}$ & $\begin{array}{l}\text { Not imp } \\
(\%)\end{array}$ & \\
\hline \multicolumn{8}{|l|}{ A. Personal barriers to physical activity } \\
\hline $\begin{array}{l}\text { 1. Do not have motivation to do physical activity, exercise } \\
\text { or sport }\end{array}$ & 13.3 & 29.1 & 57.6 & 11.6 & 51.1 & 37.3 & $<0.001$ \\
\hline 2. Not enjoying physical activity, exercise or sport & 10.8 & 18.7 & 70.5 & 10.7 & 32.1 & 57.2 & 0.0027 \\
\hline $\begin{array}{l}\text { 3. Do not have the skills to do physical activity, exercise } \\
\text { or sport }\end{array}$ & 11.3 & 21.7 & 67.0 & 15.9 & 36.7 & 47.4 & $<0.001$ \\
\hline \multicolumn{8}{|l|}{ B. Social support barriers to physical activity } \\
\hline 1. No parent's support to be physically active & 14.8 & 20.7 & 64.5 & 17.1 & 26.3 & 56.6 & 0.1838 \\
\hline 2. No friend's support to be physically active & 13.8 & 23.6 & 62.6 & 18.3 & 31.8 & 49.9 & 0.0168 \\
\hline 3. No teacher's support to be physically active & 29.6 & 24.1 & 46.3 & 30.0 & 27.8 & 42.2 & 0.5670 \\
\hline \multicolumn{8}{|l|}{ C. Environmental barriers to physical activity } \\
\hline $\begin{array}{l}\text { 1. Do not have enough information about how to increase } \\
\text { physical activity }\end{array}$ & 15.8 & 30.5 & 53.7 & 18.0 & 41.0 & 41.0 & 0.0144 \\
\hline $\begin{array}{l}\text { 2. Not having access to places to do physical activity, } \\
\text { exercise and sport }\end{array}$ & 17.2 & 25.1 & 57.7 & 24.5 & 36.1 & 39.4 & $<0.001$ \\
\hline $\begin{array}{l}\text { 3. Not being able to find physical activity facilities that are } \\
\text { inexpensive }\end{array}$ & 18.2 & 24.1 & 57.7 & 20.8 & 37.6 & 41.6 & $<0.001$ \\
\hline 4. Not having time to be physically active & 37.9 & 34.5 & 27.6 & 55.4 & 30.6 & 14.0 & $<0.001$ \\
\hline 5. Feeling shy when practising exercise outdoors & 10.3 & 18.2 & 71.5 & 13.8 & 23.2 & 63.0 & 0.1356 \\
\hline 6. The climate is not suitable for practising exercise & 35.5 & 42.9 & 21.6 & 58.7 & 30.0 & 10.4 & $<0.001$ \\
\hline $\begin{array}{l}\text { 7. Not being able to practise physical activity due to } \\
\text { cultural factors }\end{array}$ & 12.3 & 11.3 & 76.4 & 25.4 & 29.4 & 45.2 & $<0.001$ \\
\hline $\begin{array}{l}\text { 8. Do not have enough money to enrol with physical } \\
\text { activity club }\end{array}$ & 8.4 & 18.2 & 73.4 & 9.5 & 23.5 & 67.0 & 0.2777 \\
\hline
\end{tabular}

Very imp Very important barrier, S. imp somewhat important barrier, Not imp not important barrier

obese and non-obese men in relation to the barrier "Not having time to prepare or eat healthy foods because of university commitment", as $23.7 \%$ of the obese men reported that this barrier was not important, compared to $45 \%$ of non-obese men. There were no significant differences between obese and non-obese women regarding barriers to healthy eating.

The association of obesity among university students in Kuwait with perceived barriers to physical activity by gender is presented in Table 5. There were statistically significant differences between obese and non-obese men for all three personal barriers ( $P$ values were $0.027,0.005$ and 0.012). However, this was not the case for women. Although obese men and women reported that most of the barriers to physical activity were very important or somewhat important, there were no significant differences between the obese and non-obese regarding these barriers, except for the barrier "Feeling shy when practising exercise outdoors" among women, and personal barriers among men.

\section{Discussion}

The current study demonstrated that there were several personal, environmental and social barriers related to healthy eating and physical activity facing young adults in Kuwait. However, the magnitude of these barriers varies between men and women, and between obese and non-obese subjects. With regard to barriers to healthy eating, men were more willing to report that these barriers were very important than women. In contrast, men were more prone than women to report that barriers to physical activity were not important. Obesity had a different association with these barriers for men and women. It seems that obese men face more barriers to healthy eating than non-obese men, while this situation existed less among women.

Lack of information on healthy eating combined with not having skills to plan, shop for, prepare or cook healthy foods seem to be important barriers to healthy eating among Kuwaiti young adults. These findings are in agreement with those reported in Western countries [13, 15]. Nutrition 
Table 4 Perceived barriers to healthy eating among university students in Kuwait by obesity status (non-obese $=93$ men, 253 women; obese $=110$ men, 74 women)

\begin{tabular}{|c|c|c|c|c|c|c|c|c|c|}
\hline \multirow[t]{2}{*}{ Barriers } & \multirow{2}{*}{$\begin{array}{l}\text { Obesity } \\
\text { status }\end{array}$} & \multicolumn{3}{|c|}{$\operatorname{Men}(N=203)$} & \multirow[t]{2}{*}{$P$ value } & \multicolumn{3}{|c|}{ Women $(N=327)$} & \multirow[t]{2}{*}{$P$ value } \\
\hline & & $\begin{array}{l}\text { Very imp } \\
(\%)\end{array}$ & $\begin{array}{l}\text { S. imp } \\
(\%)\end{array}$ & $\begin{array}{l}\text { Not imp } \\
(\%)\end{array}$ & & $\begin{array}{l}\text { Very imp } \\
(\%)\end{array}$ & $\begin{array}{l}\text { S. imp } \\
(\%)\end{array}$ & $\begin{array}{l}\text { Not imp } \\
(\%)\end{array}$ & \\
\hline \multicolumn{10}{|c|}{ Personal and environmental barriers to healthy eating } \\
\hline \multirow{2}{*}{$\begin{array}{l}\text { 1. Do not have enough } \\
\text { information about a healthy } \\
\text { diet }\end{array}$} & Non-obese & 22.6 & 30.1 & 47.3 & 0.1072 & 16.7 & 40.3 & 43.0 & 0.4766 \\
\hline & Obese & 18.2 & 44.5 & 37.3 & & 10.8 & 43.2 & 46.0 & \\
\hline \multirow{2}{*}{$\begin{array}{l}\text { 2. Do not have motivation to eat } \\
\text { healthy diet }\end{array}$} & Non-obese & 15.1 & 38.7 & 46.2 & 0.3593 & 15.4 & 40.3 & 44.3 & 0.3936 \\
\hline & Obese & 21.0 & 41.8 & 37.2 & & 21.6 & 40.5 & 37.9 & \\
\hline \multirow{2}{*}{$\begin{array}{l}\text { 3. Do not enjoy eating healthy } \\
\text { foods }\end{array}$} & Non-obese & 19.4 & 38.7 & 41.9 & 0.0665 & 15.8 & 41.9 & 42.3 & 0.4733 \\
\hline & Obese & 29.1 & 43.6 & 27.3 & & 20.3 & 44.6 & 35.1 & \\
\hline \multirow{2}{*}{$\begin{array}{l}\text { 4. Do not have skills to plan, } \\
\text { shop for, prepare or cook } \\
\text { healthy foods }\end{array}$} & Non-obese & 28.0 & 32.3 & 39.7 & 0.0049 & 24.5 & 45.5 & 30.0 & 0.9513 \\
\hline & Obese & 21.8 & 54.5 & 23.7 & & 23.0 & 47.3 & 29.7 & \\
\hline \multirow{2}{*}{$\begin{array}{l}\text { 5. Do not have access to healthy } \\
\text { foods }\end{array}$} & Non-obese & 20.4 & 32.3 & 47.3 & 0.3100 & 17.8 & 38.7 & 48.5 & 0.3224 \\
\hline & Obese & 27.3 & 35.5 & 37.2 & & 25.7 & 35.1 & 39.2 & \\
\hline \multirow{2}{*}{$\begin{array}{l}\text { 6. Not able to buy healthy foods } \\
\text { that are inexpensive }\end{array}$} & Non-obese & 9.7 & 21.5 & 68.8 & 0.3502 & 7.5 & 19.0 & 73.5 & 0.9488 \\
\hline & Obese & 13.6 & 27.3 & 59.1 & & 8.1 & 20.3 & 71.6 & \\
\hline \multicolumn{10}{|l|}{ Social barriers to healthy eating } \\
\hline \multirow{2}{*}{$\begin{array}{l}\text { 1. No parent's support to eat } \\
\text { healthy diet }\end{array}$} & Non-obese & 12.9 & 20.4 & 66.7 & 0.6056 & 11.9 & 18.5 & 69.6 & 0.5317 \\
\hline & Obese & 14.5 & 25.5 & 60.0 & & 12.2 & 24.3 & 63.5 & \\
\hline \multirow{2}{*}{$\begin{array}{l}\text { 2. No friend's support to eat } \\
\text { healthy diet }\end{array}$} & Non-obese & 21.5 & 24.7 & 53.8 & 0.0644 & 17.0 & 29.5 & 52.5 & 0.0632 \\
\hline & Obese & 19.1 & 40.0 & 40.9 & & 23.0 & 39.2 & 37.8 & \\
\hline \multirow{2}{*}{$\begin{array}{l}\text { 3. No teacher's support to eat } \\
\text { healthy diet }\end{array}$} & Non-obese & 25.8 & 21.5 & 52.7 & 0.2806 & 17.4 & 28.9 & 53.7 & 0.1378 \\
\hline & Obese & 25.4 & 31.0 & 43.6 & & 27.0 & 29.7 & 43.3 & \\
\hline \multirow{2}{*}{$\begin{array}{l}\text { 4. Not having time to prepare or } \\
\text { eat healthy foods because of } \\
\text { university commitment }\end{array}$} & Non-obese & 31.2 & 23.7 & 45.1 & 0.0013 & 42.7 & 33.2 & 24.1 & 0.6938 \\
\hline & Obese & 31.8 & 44.5 & 23.7 & & 41.9 & 37.8 & 20.3 & \\
\hline
\end{tabular}

Very imp very important barrier, $S$. imp somewhat important barrier, Not imp not important barrier

education programmes for the public in Arab countries, including Kuwait, have been found to be deficient and outdated [16]. This may lead people to search for nutrition knowledge from other unreliable sources, especially commercial magazines and websites. El-Sabban and Bader [17] found that the nutrition knowledge of university students in Kuwait had several deficiencies in some areas of knowledge; therefore, the investigators recommended the establishment of a simplified compulsory course, focused on healthy nutrition and lifestyle for all university students.

Most people, including university students, depend on their physicians as reliable sources of nutrition information [18]. However, several studies have shown that physicians lack much essential knowledge of nutrition [19, 20]. In Kuwait, it was reported that physicians provided inaccurate nutrition information related to common health problems such as obesity, hypertension and osteoporosis. It has been suggested that a nutrition course should be introduced into medical education at universities, as well as refreshment training courses for physicians [21]. Given the lack of nutrition information among university students and physicians, there is a need to implement educational nutrition programmes in Kuwait and other Arab countries, either through the mass media or school and university curricula.

The support of parents appears not to be an important barrier among university students, which may indicate that the parents advocate that their sons and daughters eat a healthy diet. Parents provide the environment in the home for the early experiences with foods and eating habits [22]. It is well documented that parents play a considerable role in the eating of healthy foods such as fruits and vegetables [23]. The nutritional knowledge and habits of parents have a significant impact on the eating behaviour of their children [24]. Some studies in the West have shown that parents lack adequate knowledge of healthy nutrition [25, 26]. Therefore, the nutrition background and skills of parents can help to promote the healthy eating of the family members.

More than $50 \%$ of Kuwaiti university students in this study perceived that they received less support from friends and teachers for eating healthy foods. In the USA, Stepherd 
Table 5 Perceived barriers to physical activity among university students in Kuwait by obesity status (non-obese $=93$ men, 253 women; obese $=110$ men, 74 women)

\begin{tabular}{|c|c|c|c|c|c|c|c|c|c|}
\hline \multirow[t]{2}{*}{ Barriers } & \multirow{2}{*}{$\begin{array}{l}\text { Obesity } \\
\text { status }\end{array}$} & \multicolumn{3}{|c|}{$\operatorname{Men}(N=203)$} & \multirow[t]{2}{*}{$P$ value } & \multicolumn{3}{|c|}{ Women $(N=327)$} & \multirow[t]{2}{*}{$P$ value } \\
\hline & & $\begin{array}{l}\text { Very imp } \\
(\%)\end{array}$ & $\begin{array}{l}\text { S. imp } \\
(\%)\end{array}$ & $\begin{array}{l}\text { Not imp } \\
(\%)\end{array}$ & & $\begin{array}{l}\text { Very imp } \\
(\%)\end{array}$ & $\begin{array}{l}\text { S. imp } \\
(\%)\end{array}$ & $\begin{array}{l}\text { Not imp } \\
(\%)\end{array}$ & \\
\hline \multicolumn{10}{|l|}{ A. Personal barriers to physical activity } \\
\hline \multirow{2}{*}{$\begin{array}{l}\text { 1. Do not have motivation to do } \\
\text { physical activity, exercise or } \\
\text { sport }\end{array}$} & Non-obese & 9.7 & 22.6 & 67.7 & 0.0270 & 10.7 & 52.2 & 37.1 & 0.5655 \\
\hline & Obese & 16.4 & 34.5 & 49.1 & & 14.9 & 47.3 & 37.8 & \\
\hline \multirow{2}{*}{$\begin{array}{l}\text { 2. Not enjoying physical activity, } \\
\text { exercise or sport }\end{array}$} & Non-obese & 6.5 & 18.8 & 81.7 & 0.0053 & 9.9 & 31.6 & 58.5 & 0.5697 \\
\hline & Obese & 14.5 & 24.5 & 61.0 & & 13.5 & 33.8 & 52.7 & \\
\hline \multirow{2}{*}{$\begin{array}{l}\text { 3. Do not have the skills to do } \\
\text { physical activity, exercise or } \\
\text { sport }\end{array}$} & Non-obese & 6.5 & 16.1 & 77.4 & 0.0121 & 11.4 & 35.6 & 49.0 & 0.0928 \\
\hline & Obese & 15.5 & 26.4 & 58.1 & & 17.6 & 40.5 & 41.9 & \\
\hline \multicolumn{10}{|c|}{ B. Social support barriers to physical activity } \\
\hline \multirow{2}{*}{$\begin{array}{l}\text { 1. No parent's support to be } \\
\text { physically active }\end{array}$} & Non-obese & 12.9 & 21.5 & 65.6 & 0.7813 & 18.2 & 28.5 & 53.4 & 0.0928 \\
\hline & Obese & 16.4 & 20.0 & 63.6 & & 13.5 & 18.9 & 67.6 & \\
\hline \multirow{2}{*}{$\begin{array}{l}\text { 2. No friend's support to be } \\
\text { physically active }\end{array}$} & Non-obese & 11.8 & 21.5 & 66.7 & 0.5286 & 18.6 & 34.0 & 47.4 & 0.2205 \\
\hline & Obese & 15.5 & 25.5 & 59.1 & & 17.6 & 24.3 & 58.1 & \\
\hline \multirow{2}{*}{$\begin{array}{l}\text { 3. No teacher's support to be } \\
\text { physically active }\end{array}$} & Non-obese & 29.0 & 21.5 & 49.5 & 0.6446 & 27.3 & 28.1 & 44.6 & 0.1141 \\
\hline & Obese & 30.0 & 26.4 & 43.6 & & 39.2 & 27.0 & 33.8 & \\
\hline \multicolumn{10}{|c|}{ C. Environmental barriers to physical activity } \\
\hline \multirow{2}{*}{$\begin{array}{l}\text { 1. Do not have enough } \\
\text { information about how to } \\
\text { increase physical activity }\end{array}$} & Non-obese & 18.3 & 22.6 & 59.1 & 0.0617 & 17.0 & 43.1 & 39.9 & 0.3342 \\
\hline & Obese & 32.0 & 62.0 & 107 & & 59.0 & 33.8 & 44.6 & \\
\hline \multirow{2}{*}{$\begin{array}{l}\text { 2. Not having access to places to } \\
\text { do physical activity, exercise } \\
\text { or sport }\end{array}$} & Non-obese & 22.6 & 22.5 & 54.9 & 0.1727 & 23.3 & 36.8 & 39.9 & 0.7720 \\
\hline & Obese & 12.7 & 27.3 & 60.0 & & 28.4 & 33.8 & 37.8 & \\
\hline \multirow{2}{*}{$\begin{array}{l}\text { 3. Not being able to find physical } \\
\text { activity facilities that are } \\
\text { inexpensive }\end{array}$} & Non-obese & 16.1 & 25.8 & 58.1 & 0.7342 & 19.0 & 37.5 & 43.5 & 0.2534 \\
\hline & Obese & 20.0 & 22.7 & 57.3 & & 27.0 & 37.8 & 35.2 & \\
\hline \multirow{2}{*}{$\begin{array}{l}\text { 4. Not having time to be } \\
\text { physically active }\end{array}$} & Non-obese & 31.2 & 34.4 & 34.4 & 0.0839 & 26.5 & 27.7 & 15.8 & 0.0552 \\
\hline & Obese & 43.6 & 34.5 & 21.9 & & 51.4 & 40.5 & 8.1 & \\
\hline \multirow{2}{*}{$\begin{array}{l}\text { 5. Feeling shy when practising } \\
\text { exercise out door }\end{array}$} & Non-obese & 7.5 & 19.4 & 73.1 & 0.4710 & 11.9 & 21.7 & 66.4 & 0.0476 \\
\hline & Obese & 12.7 & 17.3 & 70.0 & & 20.3 & 28.3 & 51.4 & \\
\hline \multirow{2}{*}{$\begin{array}{l}\text { 6. The climate is not suitable for } \\
\text { practising exercise }\end{array}$} & Non-obese & 31.2 & 43.6 & 25.8 & 0.3261 & 59.3 & 30.0 & 10.7 & 0.8174 \\
\hline & Obese & 39.1 & 42.7 & 18.2 & & 56.8 & 33.8 & 9.4 & \\
\hline \multirow{2}{*}{$\begin{array}{l}\text { 7. Not being able to practise } \\
\text { physical activity due to } \\
\text { cultural factors }\end{array}$} & Non-obese & 10.8 & 8.6 & 80.6 & 0.3904 & 25.3 & 29.2 & 45.5 & 0.9915 \\
\hline & Obese & 13.6 & 13.6 & 72.8 & & 25.7 & 29.7 & 44.6 & \\
\hline \multirow{2}{*}{$\begin{array}{l}\text { 8. Do not have enough money to } \\
\text { enrol with physical activity } \\
\text { club }\end{array}$} & Non-obese & 9.7 & 14.0 & 76.3 & 0.3246 & 9.1 & 22.5 & 66.4 & 0.6062 \\
\hline & Obese & 7.9 & 33.6 & 71.0 & & 10.8 & 27.0 & 62.2 & \\
\hline
\end{tabular}

Very imp very important barrier, S Imp somewhat important barrier, Not imp not important barrier

et al. [27] reported that peers and teachers were the least commonly cited sources of nutrition information. However, despite that, several studies have indicated that peers and teachers can be efficiently employed in providing nutrition intervention [28, 29].

A sedentary lifestyle, which includes long periods of viewing television, playing video games, using the internet and using cars for all transportation, have become typical of the lifestyle of Kuwaiti adolescents
[4]. Kuwait experienced nutrition transition earlier than most Arab countries, which has resulted in a great change in socio-economic status and a marked alteration in the way of life. The World Health Organization [30] reported that $65 \%$ of Kuwaiti adults aged 15 years and above were less active. Therefore, promoting physical activity among Kuwaiti people has to be one of the main elements of any programme to promote a healthy lifestyle. 
This study showed that having a hot climate and not having time to be physically active were the main barriers for both males and females. It is well known that Arab Gulf countries, including Kuwait, are characterized by a long summer season, which may continue for about six months. Therefore, the chance to exercise outdoors during the year is less for Kuwaiti people than it is for those in Western countries. However, lack of time to practise physical activity was also mentioned as a barrier in the Western countries [31].

In general, the differences between men and women in barriers to physical activity in the current study were highly statistically significant, with a higher reporting by women of the categories important and somewhat important for most of these barriers. This could be due to socio-cultural factors that favour men, since in other Arab Gulf countries Kuwaiti women have less access to sports facilities than men. For cultural and religious reasons, many families do not allow their women to practise exercise at the same place as men, to practise exercise outdoors or to use sports dress to exercise outdoors [2]. Therefore, it is not surprising that "Do not have motivation to do physical activity, exercise or sport" was perceived as a barrier more by women than by men in this study.

Although obese university students in this study perceived the barriers to healthy eating as very important or somewhat important more than non-obese students, the differences between the two groups were not significant, except for two barriers among women. This could be attributed to both groups being keen to control their diet and eat some healthy food. Nevertheless, such a finding needs further in-depth investigation, which is beyond the scope of this study. As for the barriers to physical activity, the picture is slightly different. Obese men faced more significant personal barriers than non-obese men. These barriers are: "Do not have motivation to do physical activity", "Not enjoying physical activity" and "Do not have skills to do physical activity". This may be due to obese men experiencing more personal problems associated with their weight.

This study has two limitations which should be mentioned. First, weight and height were based on selfreporting, but not on actual measurements. This may affect the prevalence of obesity in the sample. Also, excluding those who did not know their weight and/or height was considered as a limitation, due to the reduced sample size. However, it is strongly believed that university students who reported their weight and height were actually aware of these measurements. Second, the study should have included more socio-cultural barriers, especially those related to physical activity. Lack of data on prevalence of smoking among university students is also considered as one of the limitations, as smoking habits may be associated with some barriers to weight maintenance. Alcohol drinking may also be associated with healthy eating and physical activity. However, it is worth mentioning that the Kuwaiti authority bans selling and consumption of all types of alcoholic drinks. Nonetheless, this study is the first attempt to investigate barriers to weight maintenance among university students in Kuwait and may be the first in Arab countries as well. Its findings can be used as the basis for further in-depth studies and for intervention activities to promote a healthy lifestyle among the Kuwaiti population.

The current health situation of young Kuwait men and women is characterized by the high availability of unhealthy foods coupled with sedentary lifestyle. This environment is promoting a high prevalence of overweight and obesity. Therefore, to combat the epidemic of obesity and related comorbidities, Kuwait authority should first correct the current environment. The results of this study highlighted some of the barriers that are associated with negative nutrition and unhealthy lifestyles in Kuwaiti young people. A preventive plan of action to overcome barriers to healthy eating and physical activity in Kuwait is urgently needed and should take into consideration the support from families and teachers, time management, selfmotivation, increased nutrition awareness, socio-cultural variables, and the provision of facilities for university men and women to practice physical activity inside and outside the university. Increasing the availability of healthy foods in university canteens and providing an environment that encourages physical activity are also essential elements for supporting a healthy lifestyle among this age group. We hope that this study stimulates other researchers to carry out further in-depth studies related to factors that are associated with unhealthy eating and sedentary lifestyle in the Arab world.

Conflict of interest The authors declare that they have no conflict of interest.

\section{References}

1. World Health Organization (WHO). Obesity and managing the global epidemic. WHO Technical Report Series 894, WHO, Geneva, Switzerland, 1998.

2. Musaiger AO. Overweight and obesity in Eastern Mediterranean region: prevalence and possible causes. J Obes. 2011; p. 1-17. doi:10.1155/2011/407237.

3. Goh YY, Bogart LM, Sipple-Asher BK, Uyeda K, Hawes-Dawson J, Olarita-Dhungana J, et al. Using community-based participatory research to identify potential intervention to overcome barriers to adolescents' healthy eating and physical activity. J Beh Med. 2009;32:491-502.

4. Al-Haifi AR, Al-Fayez MA, Al-Athari BI, Al-Ajmi FA, Allafi AR, Al-Hazzaa HM, et al. Relative contribution of physical activity, sedentary behavior, and dietary habits to the prevalence of obesity among Kuwaiti adolescents. Food Nutr Bull. 2013;34:6-13. 
5. Moussa MA, Shaltout AA, Nkonsa-Dwamena D, Mourad M, Alshsheikh N, Agha N, et al. Factors associated with obesity in Kuwaiti children. Eur J Epidemiol. 1999;15:41-9.

6. Al-Isa AN, Comphell J, Desapriya E. Factors associated with overweight and obesity among Kuwaiti men. Asia Pac J Public Health. 2013;25:63-73.

7. Al-Kandari YY. Prevalence of obesity in Kuwait and its relation to socio-cultural variables. Obes Rev. 2006;7:147-54.

8. LaCaille LT, Dauner KN, Krambeer RJ, Bas JP. Psychosocial and environmental determinants of eating behaviours, physical activity and weight change among college students: qualitative analysis. J Am College Health. 2011;59:531-8.

9. Skinner K, Hanning RM, Tsuji LTS. Barriers and supports for healthy eating and physical activity for first nation's youths in Northern Canada. Int J Circumpolar Health. 2006;65:148-61.

10. Al-Isa AN. Factors associated with overweight and obesity among Kuwaiti college women. Nutr Health. 1998;12:227-33.

11. Al-Isa AN. Factors associated with overweight and obesity among Kuwaiti college men. Br J Nutr. 1999;82:369-74.

12. El-Ghazali S, Ibrahim JM, Kanari BM, Ismail NA. The relationship between lifestyle and body mass index among university students in Kuwait. Egypt J Comm Med. 2010;28:69-76.

13. Andajani-Suljahjo S, Ball K, Warren N, Inglis V, Crowford D. Perceived personal, social and environmental barriers to weight maintenance among young women: a community survey. Int $\mathbf{J}$ Behav Nutr Phys Act. 2004;1:15. doi:10.1186/1479-5868-1-15.

14. Musaiger AO, Al-Mannai M, Tayyem R, Al-lala O, Ali EYA, Kalam F, et al. Perceived barriers to healthy eating and physical activity among adolescents in seven Arab countries: a crosssectional study. Sci J. 2013; p. 232164. doi:10.1155/2013/ 232164

15. Croll JK, Neumark-Sztainer D, Story M. Healthy eating: what does it mean to adolescents? J Nutr Educ. 2001;33:193-8.

16. Musaiger AO, Hassan AS, Obeid O. The paradox of nutritionrelated diseases in the Arab countries: the need for action. Int $\mathrm{J}$ Env Res Pub Health. 2011;8:3637-71.

17. El-sabban F, Badr HC. Assessment of nutritional knowledge and related aspects among first-year Kuwait university students. Ecol Food Nutr. 2011;50:181-95.

18. Ward R. Talking with your patients about dietary cholesterol, diet and nutrition: best practices for family physicians. Int J Clin Pract Suppl. 2009;163(22-26):52-7.
19. Helman A. Nutrition and general practice: an Australian perspective. Am J Clin Nutr. 1997;65:1939-42.

20. Al-Madani KM, Landman J, Musaiger AO. Nutrition knowledge, attitudes and practices: a comparison between medical practitioners and medical students in Bahrain. Health Educ. 2004;104: 90-9.

21. Allafi AR, Alajmi F, Al-Haifi A. Survey of nutrition knowledge of physicians in Kuwait. Public Health Nutr. 2013;16:1332-6.

22. Findhalt NE, Michael YL, Jerofke LT, Brogoilli VW. Environmental influences on children's physical activity and eating habits in rural Oregon country. Am J Health Promot. 2011;26:74-85.

23. Young EM, Fors SW, Hayes DM. Association between perceived parents behaviours and middle school students' fruit and vegetables consumption. J Nutr Educ Behav. 2004;36:2-8.

24. Benton D. Role of parents in the determination of the food preferences of children and development of obesity. Int $\mathrm{J}$ Obes Relat Metab Disord. 2004;28:858-69.

25. Birch LL, Darison KK. Family environmental factors influencing the developing behavioural controls of food intake and childhood overweight. Pediatr Clin North Am. 2001;48:893-907.

26. Seaglioni S, Salvioni M, Galimberti C. Influence of parental attitudes in the development of children eating behavior. $\mathrm{Br} \mathrm{J}$ Nutr. 2008;99(Suppl 1):S22-5.

27. Stepherd J, Harden A, Rees R, Brunton G, Garcia J, Olives S, et al. Young people and healthy eating: a systematic review of research on barriers and facilitators. Health Educ Res. 2005;12:239-57.

28. Belonger M, Casey M, Cormier M, Filion Al, Martin G, Aubat S, et al. Maintenance and decline of physical activity during adolescence: insights from a qualitative study. Int J Behav Nutr Physical Act. 2011;8:117-25.

29. Chen YH, Yeh CY, Lai YM, Shyu ML, Huang KC, Chiou HY. Significant effects of implementation of health-promoting schools on schoolteachers' nutrition knowledge and dietary intake in Taiwan. Public Health Nutr. 2010;13(4):579-88.

30. World Health Organization. STEP-wise approach to surveillance (STEPS). http://www.who.int/chp/steps/enl. Accessed $17 \mathrm{Sept}$ 2011.

31. Targerson JL, King KA. Do perceived cues, benefits and barriers to physical activity differ between male and female adolescents? J Sch Health. 2002;72:374-80. 